\title{
Examining the Content Validity of Android-Based Augmented Reality Media for Chemical Bonding using Rasch Model
}

\author{
Sri Yamtinah ${ }^{1 *}$, Sri Retno Dwi Ariani ${ }^{1}$, Martha Andriyanti ${ }^{1}$, Sulistyo Saputro ${ }^{1}$, Endang Susilowati ${ }^{1}$, \\ Ari Syahidul Shidiq1, Dimas Gilang Ramadhani1 ${ }^{1}$, Isma Aziz Fakhrudin ${ }^{1}$ \\ ${ }^{1}$ Chemistry education, Sebelas Maret University, Surakarta, Indonesia
}

\section{DOI: $10.29303 /$ ippipa.v7iSpecialIssue.1094}

\section{Article Info}

Received: November $5^{\text {th }}, 2021$

Revised: December 13th 2021

Accepted: December 16th, 2021

\begin{abstract}
: 21st-century learning presents chemistry teachers with new challenges in teaching abstract chemistry concepts with various technologies that continue to develop. One of the media that can visualize abstract chemical concepts is Augmented Reality (AR). AR media developed in chemistry learning needs to be valid so that it can be used properly. Therefore, this study aims to examine the validity of the Android-based AR media developed. Four education practitioners carried out the validation as experts, and 13 students participated as respondents. The instrument used is a questionnaire with a Likert scale. The data obtained were analyzed quantitatively with the Rasch model using the facet software. The results of the analysis show that the Exact Agreements are $41.10 \%$, and the Expected Agreements are $42.20 \%$. The most challenging aspect to achieve is media design, while profit is the most easily agreed-upon aspect. Based on this assessment, in the development of augmented reality media, it is necessary to pay attention to display aspects and $3 \mathrm{D}$ objects suitable for viewing a material so that it is easier for users to understand the material.
\end{abstract}

Keywords: Augmented reality; Chemical bonding; Rasch model; Validity

Citation: Yamtinah, S., Ariani, S.R.D., Andriyanti, M., Saputro, S., Susilowati, E., Shidiq, A.S., Ramadhani, D.G., \& Fakhrudin, I.A. (2021). Examining the Content Validity of Android-Based Augmented Reality Media for Chemical Bonding using Rasch Model. Jurnal Penelitian Pendidikan IPA, 7(Speciallssue), 320-325. https://doi.org/10.29303/jppipa.v7iSpeciallssue.1094

\section{Introduction}

Teaching abstract chemistry concepts is challenging for chemistry teachers (Abdinejad, et al., 2020; Crandall, et al., 2015; Yamtinah, et al., 2019). In addition, many students and even university students find chemistry difficult and complex (Herga, et al., 2016; Woldeamanuel, et al., 2014). One of the abstract and challenging topics for students is the 3-dimensional visualization of molecular structure, chemical reactions, stereochemistry, chemical bonds, and sub-microscopic representations (Abdinejad, et al., 2020; Battle, et al., 2010; Gilbert \& Treagust, 2009). In chemistry learning, teachers and students need to represent mental models on a molecular scale (Chittleborough \& Treagust, 2007).
However, representation and visualization of molecular mental models that are less clear can often make it difficult for students to understand chemistry and see its relevance in their lives in society (Venkataraman, 2009). Therefore, represent and visualize 2D images in student textbooks into actual 3D structures for today's chemistry learning (Abdinejad, et al., 2020; Othman, et al., 2008; Venkataraman, 2009).

Based on the challenges of learning chemistry, there is a need to develop learning materials that can help students understand chemical concepts as well as promote motivation of students to study chemistry (Sari, et al., 2014). Media by applying science and technology can increase the effectiveness and efficiency of the learning process, as it can help students 
understand the subject (Arifin, ar al., 2018; Shidiq, et al., 2021). Augmented reality (AR) is a technology that can be used to visualize an abstract concept that is difficult to understand (Elisa \& Wiratmaja, 2019; Kesim \& Ozarslan, 2012; Abdinejad, et al., 2020). Augmented reality combines the real world and the virtual world where three-dimensional virtual objects are projected into the real environment (Cai, et al., 2014; Salmi, et al., 2012).

One of the advantages of $A R$ is that it can provide 3D visualization and can be used on Android smartphones (Irwansyah, et al., 2017). Several studies have shown that augmented reality can support chemistry learning because it can improve students' spatial visualization (Fitriani, et al., 2019; Abdinejad, et al., 2020). In this study, augmented reality media is packaged as an Android-based application. Based on the results of the initial analysis, the selection of Android-based media is due to the fact that most of the students are already using Android-based mobile phones. It is therefore hoped that with this medium, the students will be able to easily access this medium and will be able to help the students to understand the chemical concepts.

In the development of augmented reality media, tests are needed to determine whether the media is workable or not and can find out which aspects are difficult to achieve and easy to achieve. Validity is a method that can be used to determine the feasibility of the developed media. In this study, content validity was performed to determine the feasibility of content presented in developed media. The aim of this study was to test the validity of the Android-based augmented reality media that was developed. There have been many studies on the analysis of validity in various ways (Tasrif, et al., 2020; Muzyanah, et al., 2018). This study focuses on analysis with Rasch model using Facet software. Analysis with Rasch's model can find out how the interaction between the evaluators and the elements is at the same time (Muntazhimah, et al., 2020). In addition, Rasch's model also provides information related to rater reliability, item reliability, and information related to the rater's unexpected response (Fahmina, et al., 2019).

\section{Method}

This study uses a quantitative method, where data processing and analysis uses the Rasch model with Facets software. The data used was obtained from the results of the validation of the evaluation of the product by 4 educational practitioners and 13 students who had received chemical binding material, namely the students of class XII of SMA Negeri 1 Sukoharjo. The instrument used is a questionnaire with a Likert scale with a score of 1 to 5 for each aspect measured. The aspects measured in the validation test are presented in Table 1.

Table 1. AR Media Assessment Aspects

\begin{tabular}{|c|c|}
\hline $\begin{array}{l}\text { Assessment } \\
\text { Aspects }\end{array}$ & Indicator \\
\hline Language & $\begin{array}{l}\text { Clear user manual } \\
\text { Language use }\end{array}$ \\
\hline Material & $\begin{array}{l}\text { Material clarity } \\
\text { Ease of understanding the material }\end{array}$ \\
\hline Design & $\begin{array}{l}\text { AR media design } \\
\text { Text legibility } \\
\text { Ease of use of AR applications }\end{array}$ \\
\hline Benefit & The benefits of AR media \\
\hline
\end{tabular}

The data collection was carried out after students and education practitioners used augmented reality media. Additionally, data analysis was performed by measuring faceted Rasch using faceted software. The flow of the search procedure is illustrated in Figure 1.

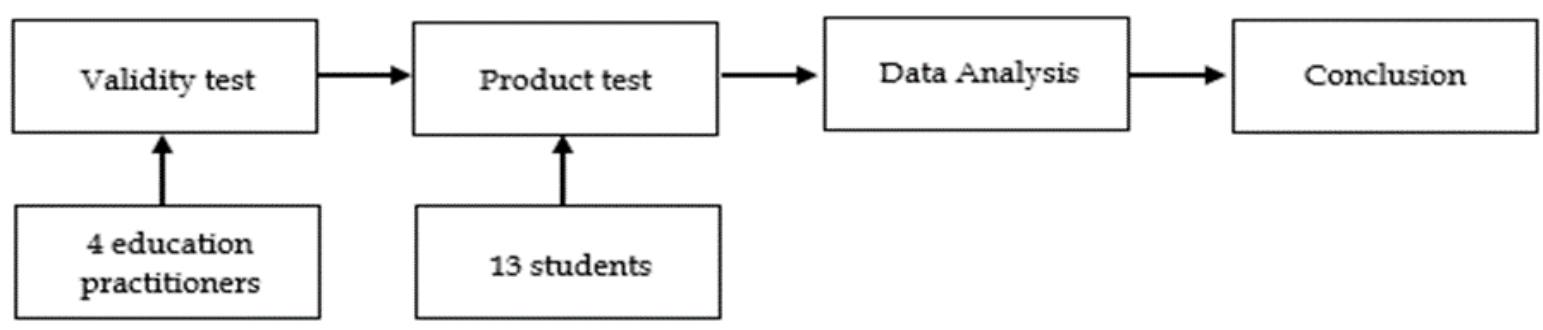

Figure 1. The flow of the research procedure

\section{Result and Discussion}

Based on the evaluation of the product by education practitioners, improvements to the product are made. From the results of the evaluation by education practitioners, it was found that this product could be tested on students after the repairs were made. Then the data from the validation results by the education practitioners and the student test results that were obtained were analyzed using the Rasch Facet 
model using the Facet software. The results of graphical measurements for elements, aspects and evaluators are shown in Figure 2.

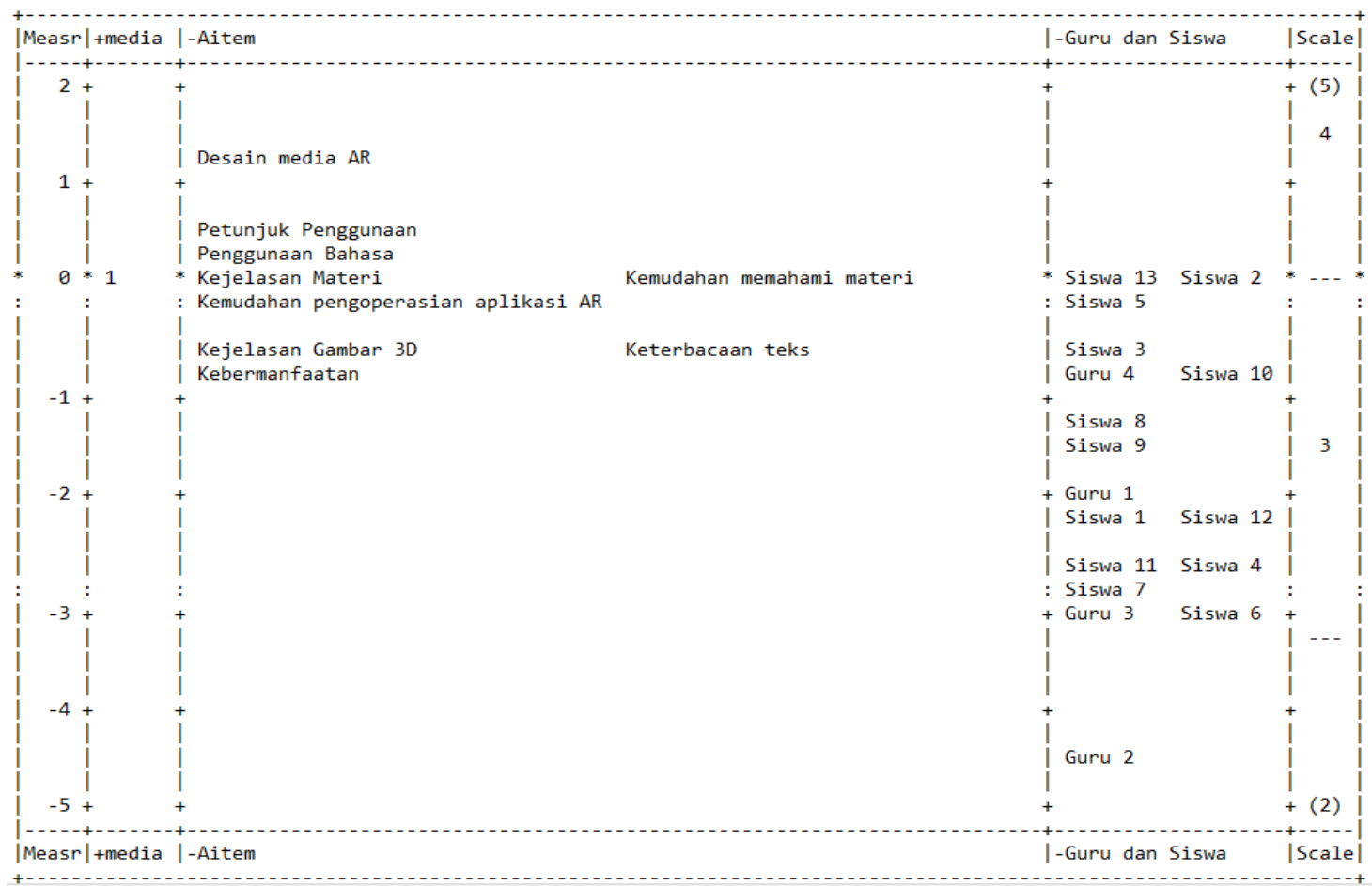

Figure 2. All facet vertical

In Figure 2. the first column shows the logit scale for all aspects, the second column shows the media products rated, the third column shows the aspects rated, while the fourth column contains the reviewers, i.e., students and students' teachers.

Based on the distribution of ratings, the location of the aspects in Figure 2. shows the level of difficulty faced by the reviewers in each aspect. The aspects considered as difficult to achieve will be in the first position, while the aspects considered to be the easiest to achieve will be in the last position. Meanwhile, in terms of raters, the rater who is the most difficult to rate will be at the top in the fourth column, in contrast, the rater who is easiest to rate is at the bottom.

In Figure 2. it can be seen that the estimated questions ranged from questions that most satisfied the aspects to those that did not meet the aspects ranging from 2 to -5 logs. The design aspect of AR media is at the highest-level logit, it shows that this aspect is at the highest level of difficulty. In contrast, the userfriendliness aspect is at the lowest logit level, which means that it is the easiest to achieve (Sabah \& Hammouri, 2009). This difference in position shows that each aspect has a different level of difficulty of achievement. The results of the multi-faceted Rasch can be seen in Table 2.
Table 2. Summary of multi-faceted rasch result

\begin{tabular}{lllll}
\hline & $\begin{array}{l}\text { Strata } \\
\text { Value }\end{array}$ & Reliability & $\begin{array}{l}\text { Exact } \\
\text { Agreements } \\
(\%)\end{array}$ & $\begin{array}{l}\text { Expected } \\
\text { Agreements } \\
(\%)\end{array}$ \\
\hline Rater & 2.63 & 0.75 & 41.10 & 42.20 \\
\hline Item & 2.73 & 0.76 & - & - \\
\hline
\end{tabular}

\section{Rater}

There are 17 reviewers used to review this product comprised of 4 education practitioners and 13 students. The results of the evaluation in Table 1. show that the reliability index is 0.75 , while the item reliability is 0.76 , which is included in the sufficient category (Sumintono \& Wahyu, 2014). This shows that the consistency of the evaluator's answers is quite strong and that the quality of the items of the instrument is quite adequate. The stratum value obtained is 2.63 or rounded to 3 , indicating that there are 3 groups of respondents (Kristiana, et al., 2019). Moreover, this stratum value also shows that the expert's results are reliable.

Based on Table 2. it can be seen that the results of the validity of the exact agreement value obtained a value of $41.10 \%$, while the Rasch model predicts $42.20 \%$. Based on these results indicate that the empirical validation is almost the same as the predicted value. Therefore, the resulting validation rating is interpreted as good because the value of Exact 
Agreements and Expected Agreements is bigger than $40.00 \%$ (Sumintono \& Wahyu, 2014).

Seen from the raters, it can be seen that the raters (student 13 and student 2) are the most difficult to grade and teacher 2 is very easy to grade. The teacher rates almost all aspects perfectly, although, on the other hand, many reviewers believe that there is still a lot of room for improvement from this media product. This can be detrimental to the development of this medium. At this stage, the evaluator should assess the strengths and weaknesses of the product content developed so that a product suitable for use can be produced. On the other hand, 13 students and 2 students tend to rate products with high standards, this can be interpreted as a shortcoming, but it can be used as an evaluation for improving the product so that a decent product could be produced later. But if there are a lot of reviewers who are in this position, then the product will be deemed unsuitable.

\section{Item}

The items in this study amounted to 1 , namely Android-based augmented reality media products. The elements are evaluated on the basis of 4 aspects, namely the linguistic aspects, the material aspects, the design (display aspects), and the advantages aspects. Each aspect consists of several sub-aspects. The linguistic aspect includes the clarity of the instructions for the use and use of the language, the material aspect consists of the clarity of the material and the ease of comprehension of the material. The design (display) aspect includes AR multimedia design, text readability, and ease of use of AR applications, while the advantage aspect is usability. Based on Table 1. the item reliability is 0.76 and the stratum value is 2.73 . This shows that the data collected is reliable. If seen in Figure 1. a very difficult aspect to achieve in this media is the design of the AR media, where this aspect resides in the 2-1 log logit. After conducting an analysis based on suggestions and comments, the part of AR media design that needs to be improved is the part of $3 \mathrm{D}$ object design. 3D objects on augmented reality media are shown in Figure 2.

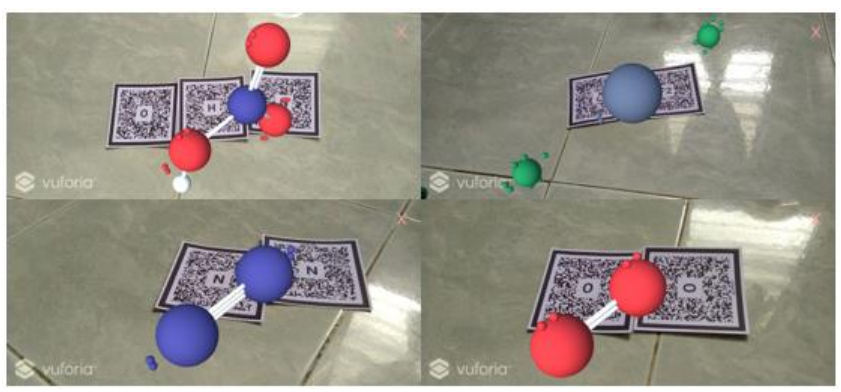

Figure 3. The aspect that is difficult to observe
Figure 3. shows that the 3D objects are still difficult to understand, this is because the atomic description is not clearly visible. In addition, the image of the object of the isolated pair of electrons in the atom is also not clearly visible, which can make it difficult for students to understand the bonding process. In addition, 3D objects are always difficult to observe in three dimensions, to see three-dimensional objects, the user has to move the phone to get the best position to see the objects from another point of view. When students rotate 3D objects to change the perspective of 3D objects, students can improve skills other than those developed by reading and writing (Cabero \& Barroso, 2016). So that the appearance of $3 D$ objects is an important thing to pay attention to.

In addition to the design of the AR media, instructions for use are also included in the aspects considered difficult, where this aspect is in the logit between 0 and $1 \log$. This is reinforced by the results of suggestions from respondents who said that the instructions for using the media were still too general and unclear.

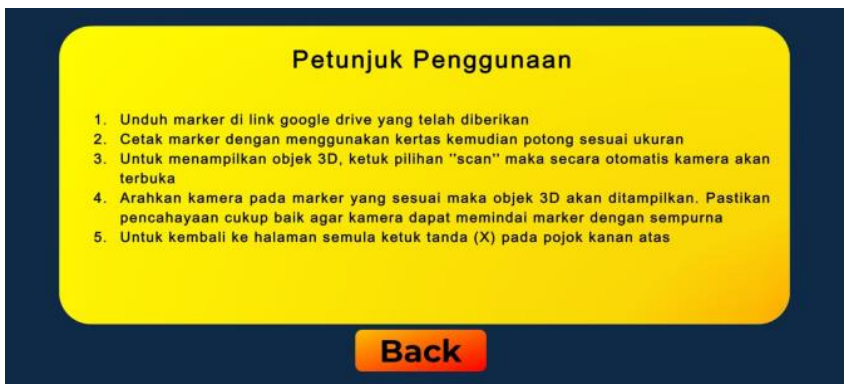

Figure 4. Display Menu Instructions

Figure 4. shows that the instructions for use are only described in general terms, which may make it difficult for users to use the multimedia product. According to Wiratama, et al., (2018) for using AR apps someone who can explain how to use AR apps is needed. In order for the AR app to be used by students on their own, the instructions for use must be clearly explained. Also, the link to download the markers is not included in the user manual, so users may have difficulty obtaining markers. Therefore, to overcome this problem, a media usage guide module accessible to users outside of this application has been created.

\section{Conclusion}

Android-based augmented reality media were tested for feasibility using a validity assessment instrument in the form of a questionnaire with a Likert scale. Where in the validation process involves education practitioners as experts and students to try 
out media products. Then, the validation results were analyzed using the Rasch model with Facet software. Based on the results of the analysis, the value of Exact Agreements was $42.20 \%$, while the Expected Agreements were $41.10 \%$. It can be seen that the empirical validation is not very different from the expected evaluation results. From an evaluation standpoint, the hard thing to achieve is the design of AR media, while what is easy to achieve is usability. Meanwhile, when viewed from the rater, Student 13 and Student 2 are very difficult to grade students, while Teacher 2 is the easiest to grade.

\section{References}

Abdinejad, M., Talaie, B., Qorbani, H. S., \& Dalili, S. (2020). Student Perceptions Using Augmented Reality and 3D Visualization Technologies in Chemistry Education. Journal of Science Education and Technology, 30(1), 87-96. https:// doi.org/10.1007/s10956-020-09880-2

Arifin, A., Suparman, A. R., \& Yogaswara, R. (2018). Pengembangan Media Pembelajaran Kimia Menggunakan Software Autoplay Media Studio Pada Pokok Bahasan Sistem Periodik Unsur. Arfak Chem: Chemistry Education Journal, 55-59. Retrieved http://jurnal.unipa.ac.id/index.php/accej [Indonesian]

Battle, G. M., Allen, F. H., \& Ferrence, G. M. (2010). Teaching three-dimensional structural chemistry using crystal structure databases. 2. Teaching units that utilize an interactive web-accessible subset of the Cambridge Structural Database. Journal of Chemical Education, 87(8), 813-818. https://doi.org/10.1021/ed100257t

Cabero, J., \& Barroso, J. (2016). The Educational Possibilities of Augmented Reality. New Approaches in Educational Research, 5(1), 44-50. https://doi.org/10.7821/naer.2016.1.140

Cai, S., Wang, X., \& Chiang, F. K. (2014). A Case Study of Augmented Reality Simulation System Application in a Chemistry Course. Computers in Human Behavior, 37, 31-40. https://doi.org/10.1016/j.chb.2014.04.018

Chittleborough, G., \& Treagust, D. F. (2007). The Modelling Ability of Non-major Chemistry Students and Their Understanding of the Submicroscopic Level. Chemistry Education Research and Practice, 8(3), 274-361. https://doi.org/10.1039/B6RP90035F

Crandall, P. G., Engler, R. K., Beck, D. E., Killian, S. A., O'Bryan, C. A., Jarvis, N., \& Clausen, E. (2015). Development of an augmented reality game to teach abstract concepts in food chemistry. Journal of Food Science Education, 14(1), 18-23. https://doi.org/10.1111/1541-4329.12048

Elisa, E., \& Wiratmaja, I. (2019). Augmented reality: Analisis Pengembangan Media Pembelajaran Kimia untuk Meningkatkan Keterampilan 4C Mahasiswa. Journal of The Indonesian Society of Integrated Chemistry, 11(2), 73-81. https://doi.org/10.22437/jisic.v11i2.8124 [Indonesian]

Fahmina, S. S., Masykuri, M., Ramadhani, D. G., \& Yamtinah, S. (2019). Content validity uses Rasch model on computerized testlet instrument to measure chemical literacy capabilities. AIP Conference Proceedings, 2194(December). https://doi.org/10.1063/1.5139755

Fitriani, E., Suhartono, S., \& Mugiarti, I. (2019). Make it real: Simulation of 3D Molecules Using Augmented Reality in Chemical Bonding Topic. Journal of Physics: Conference Series, 1402(5). https://doi.org/10.1088/17426596/1402/5/055058

Gilbert, J. K., \& Treagust, D. F. (2009). Macro, Submicro and Symbolic Representations and the Relationship Between Them: Key Models in Chemical Education. In J. K. Gilbert \& D. F. Treagust (Eds.), Multiple Representations in Chemical Education (4th ed., pp. 1-18). https:// doi.org/10.1007/978-94-007-0449-7

Herga, N. R., Cagran, B., \& Dinevski, D. (2016). Virtual laboratory in the role of dynamic visualisation for better understanding of chemistry in primary school. Eurasia Journal of Mathematics, Science and Technology Education, 12(3), 593-608. https://doi.org/10.12973/eurasia.2016.1224a

Irwansyah, F. S., Ramdani, I., \& Farida, I. (2017). The Development of an Augmented Reality (AR) Technology-Based Learning Media in Metal Structure Concept. Ideas for 21st Century Education, 233-237. https://doi.org/10.1201/9781315166575$\underline{47}$

Kesim, M., \& Ozarslan, Y. (2012). Augmented Reality in Education: Current Technologies and the Potential for Education. Procedia - Social and Behavioral Sciences, 47(222), 297-302. https://doi.org/10.1016/j.sbspro.2012.06.654

Kristiana, I. F., Fajrianthi, F., \& Purwono, U. (2019). Analisis Rasch Dalam Utrecht Work Engagement Scale-9 (Uwes-9) Versi Bahasa Indonesia. Jurnal Psikologi, 17(2), 204. https://doi.org/10.14710/jp.17.2.204-217 [Indonesian]

Muntazhimah, M., Putri, S., \& Khusna, H. (2020). Rasch Model untuk Memvalidasi Instrumen Resiliensi Matematis Mahasiswa Calon Guru Matematika. JKPM (Jurnal Kajian Pendidikan Matematika), 6(1), 
65. https://doi.org/10.30998/ikpm.v6i1.8144 [Indonesian]

Muzyanah, S., Asmaningrum, H., \& Buyang, Y. (2018). Efektivitas Penggunaan Media Edmodo Sebagai Penunjang Pembelajaran Kimia. Musamus Journal of Science Education, 1(1), 033-045. https://doi.org/10.35724/mjose.v1i1.949 [Indonesian]

Othman, J., Treagust, D. F., \& Chandrasegaran, A. L. (2008). An investigation into the relationship between students' conceptions of the particulate nature of matter and their understanding of chemical bonding. International Journal of Science Education, 30(11), 1531-1550. https://doi.org/10.1080/09500690701459897

Sabah, S., \& Hammouri, H. (2009). Validation of a Scale of Attitudes Toward Science Across Countries Using Ra. Journal of Baltic Science Education. 12(5). 692-702. Retrieved from: http://www.scientiasocialis.lt/jbse/?q=node/327

Salmi, H., Kaasinen, A., \& Kallunki, V. (2012). Towards an Open Learning Environment via Augmented Reality (AR): Visualising the Invisible in Science Centres and Schools for Teacher Education. Procedia - Social and Behavioral Sciences, 45, 284295. https://doi.org/10.1016/j.sbspro.2012.06.565

Sari, K. W., Saputro, S., \& Hastuti, B. (2014). Pengembangan Game Edukasi Kimia Berbasis Role Playing Game (RPG) Pada Materi Struktur Atom Sebagai Media Pembelajaran Mandiri Untuk Siswa Kelas X SMA Di Kabupaten Purworejo. Jurnal Pendidikan Kimia (JPK), 3(2), 96$104 . \quad$ Retrieved from: https://jurnal.fkip.uns.ac.id/index.php/kimia/ar $\underline{\text { ticle/view/3717 [Indonesian] }}$

Shidiq, A. S., Permanasari, A., Hernani, H., \& Hendayana, S. (2021). The use of simple spectrophotometer in STEM education: A bibliometric analysis. Moroccan Journal of Chemistry, 9(1), 290-300. https://doi.org/http://doi.org/10.48317/IMIST. PRSM/morjchem-v9i2.27581

Sumintono, B., \& Wahyu, W. (2014). Aplikasi Model Rasch Untuk Penelitian Ilmu-Ilmu Sosial (Edisi Revi; T. Bambang, ed.). Cimahi: Trim Komunikata Publishing House. [Indonesian]

Tasrif, E., Mubai, A., Huda, A., \& Rukun, K. (2020). Pemanfaatan Media Pembelajaran Berbasis Augmented Reality Menggunakan Aplikasi AR_Jarkom Pada Mata Kuliah Instalasi Jaringan Komputer. Jurnal Konseling Dan Pendidikan, 8(3), 217-223. $\quad$ https://doi.org/10.29210/153400 [Indonesian]

Venkataraman, B. (2009). Visualization and interactivity in the teaching of chemistry to science and non- science students. Chemistry Education Research and Practice, 10(1), 62-69. https://doi.org/10.1039/b901462b

Wiratama, I. K. A., Khrisne, D. C., \& Sudarma, M. (2018). Augmented Reality Berbasis Android Untuk Pengenalan Peralatan Laboratorium. EJournal SPEKTRUM, 5(1), 89-94. https://doi.org/10.24843/SPEKTRUM.2018.v05.i 01.p13 [Indonesian]

Woldeamanuel, M. M., Atagana, H., \& Engida, T. (2014). What makes chemistry difficult? African Journal of Chemical Education, 4(2), 31-43.

Yamtinah, S., Indriyanti, N. Y., Saputro, S., Mulyani, S., Ulfa, M., Mahardiani, L., ... Shidiq, A. S. (2019). The identification and analysis of students ' misconception in chemical equilibrium using computerized two-tier multiple-choice instrument. Journal of Physics: Conference Series, $1157 \quad$ (2019(042015), 1-7. https://doi.org/10.1088/1742$\underline{6596 / 1157 / 4 / 042015}$ 